Supporting information

\title{
Prediction of Temperature and Concentration Profiles in an Industrial Polymerization Fluidized Bed Reactor Under Condensed Mode Operation
}

\author{
Saeid Atashrouz ${ }^{1}$, Mohammad Rahmani ${ }^{1,2, *}$, Bahram Nasernejad ${ }^{2}$, João B.P. Soares ${ }^{3}$ \\ 1. Department of chemical engineering, Amirkabir University of Technology (Tehran Polytechnic), Mahshahr \\ campus, PO Box 415, Mahshahr, Iran. \\ 2. Department of Chemical Engineering, Amirkabir University of Technology (Tehran Polytechnic), Hafez 424, PO \\ Box 15875-4413, Tehran, Iran \\ 3. Department of Chemical and Materials Engineering, University of Alberta, 9211116 St, Edmonton, Alberta, T6G \\ 1H9, Canada
}

* Corresponding Author's E-mail: m.rahmani@aut.ac.ir

Tel: +98 (021) 64543198

Fax: +98 (021) 66405847 


\section{S1. Results}

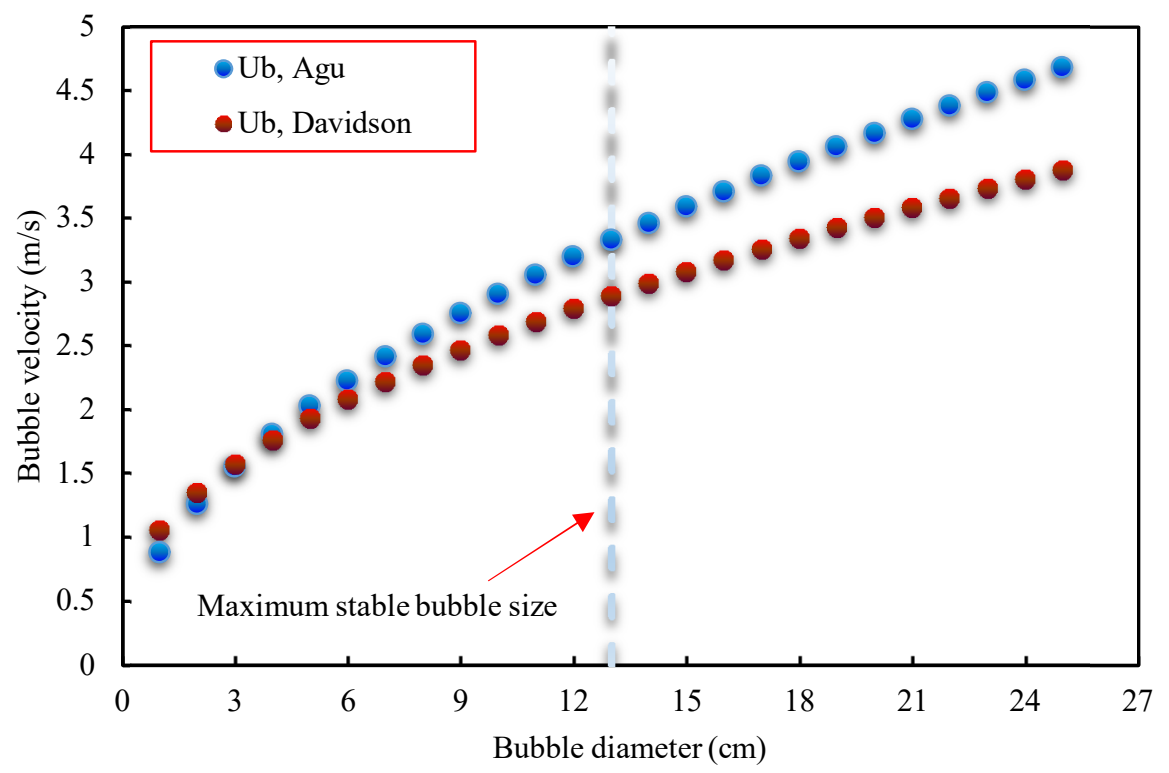

Figure S1: Comparison between Davidson and Harrison's ${ }^{1}$ correlation with the correlation of Agu et al. ${ }^{2}$ for prediction of bubble velocity. 

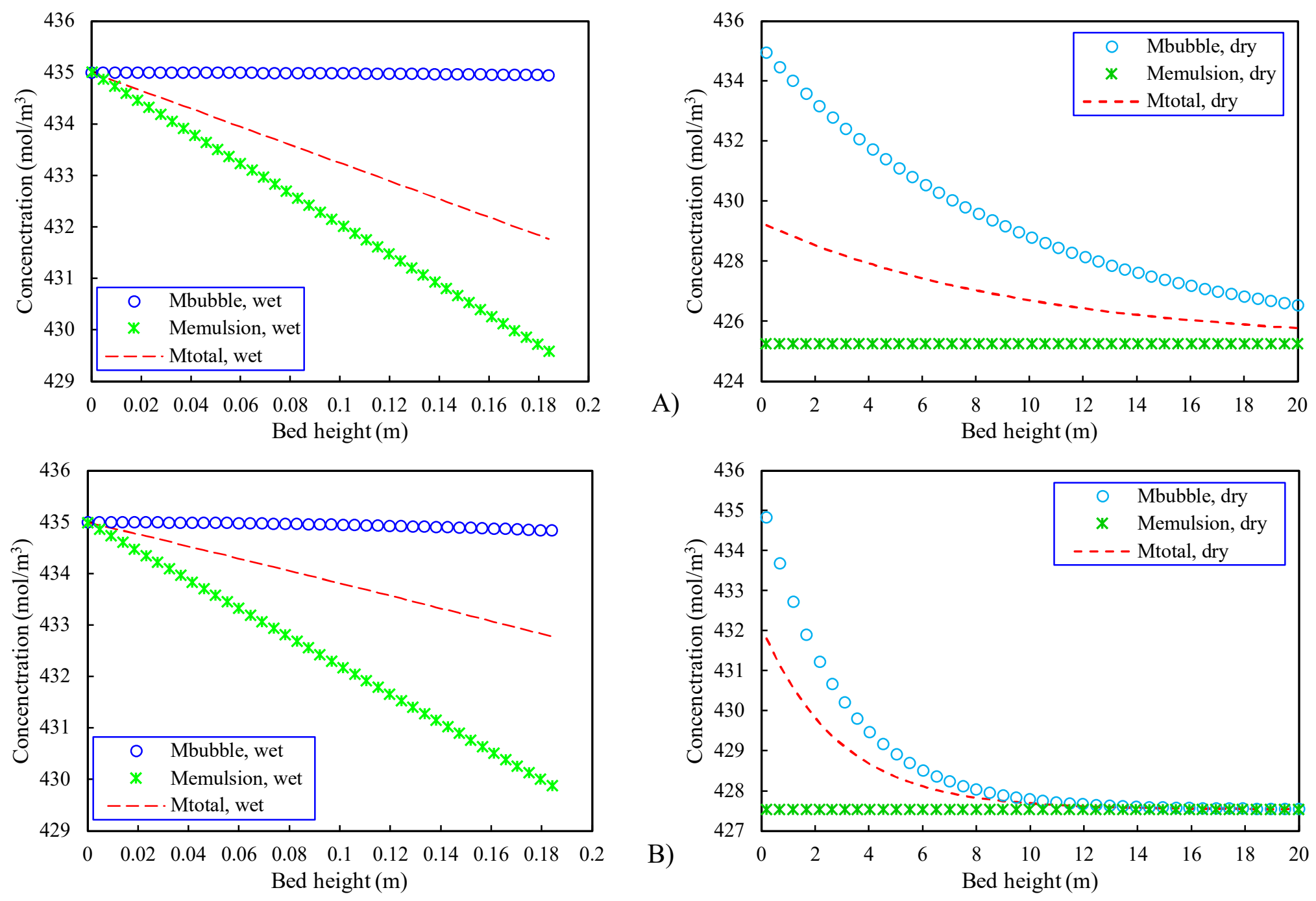

Figure S2: Effect of bubble diameter on concentration profile along the bed in wet and dry zones,

a) $\left.\mathrm{D}_{\mathrm{b}}=0.1 \mathrm{~m}, \mathrm{~b}\right) \mathrm{D}_{\mathrm{b}}=0.05 \mathrm{~m},\left(\mathrm{U}_{0}=0.65 \mathrm{~m} / \mathrm{s}, \dot{\mathrm{m}}_{\mathrm{ICA}}=70 \mathrm{ton} / \mathrm{hr}, \mathrm{Q}_{\mathrm{cat}}=0.31 \mathrm{gr} / \mathrm{s}\right)$ 

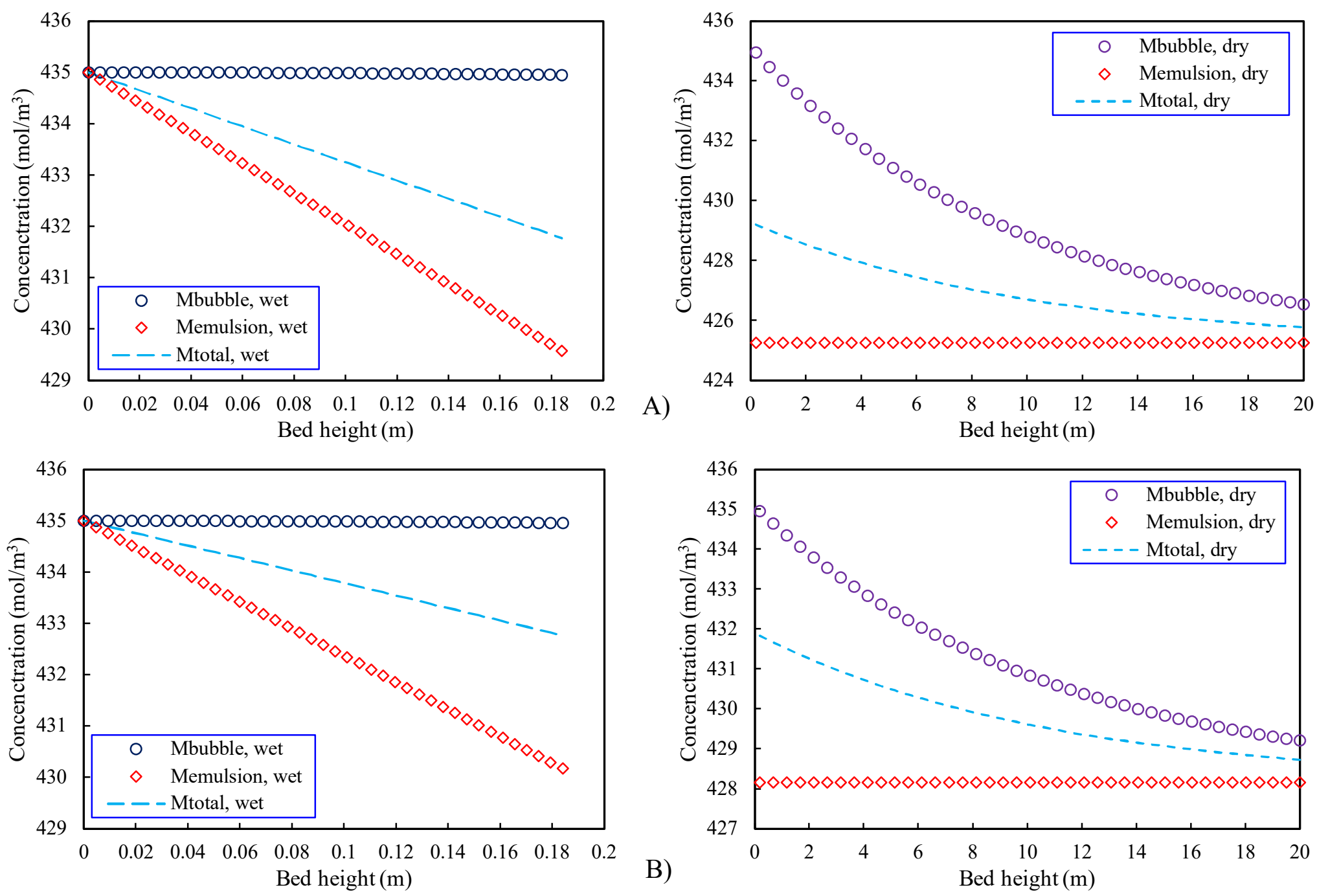

Figure S3: Effect of gas velocity on concentration profile along the bed in wet and dry zones,

a) $\mathrm{U}_{0}=0.65 \mathrm{~m} / \mathrm{s}$, b) $\mathrm{U}_{0}=0.85 \mathrm{~m} / \mathrm{s},\left(\mathrm{D}_{\mathrm{b}}=0.10 \mathrm{~m}, \dot{\mathrm{m}}_{\mathrm{ICA}}=70 \mathrm{ton} / \mathrm{hr}, \mathrm{Q}_{\text {cat }}=0.31 \mathrm{gr} / \mathrm{s}\right)$ 

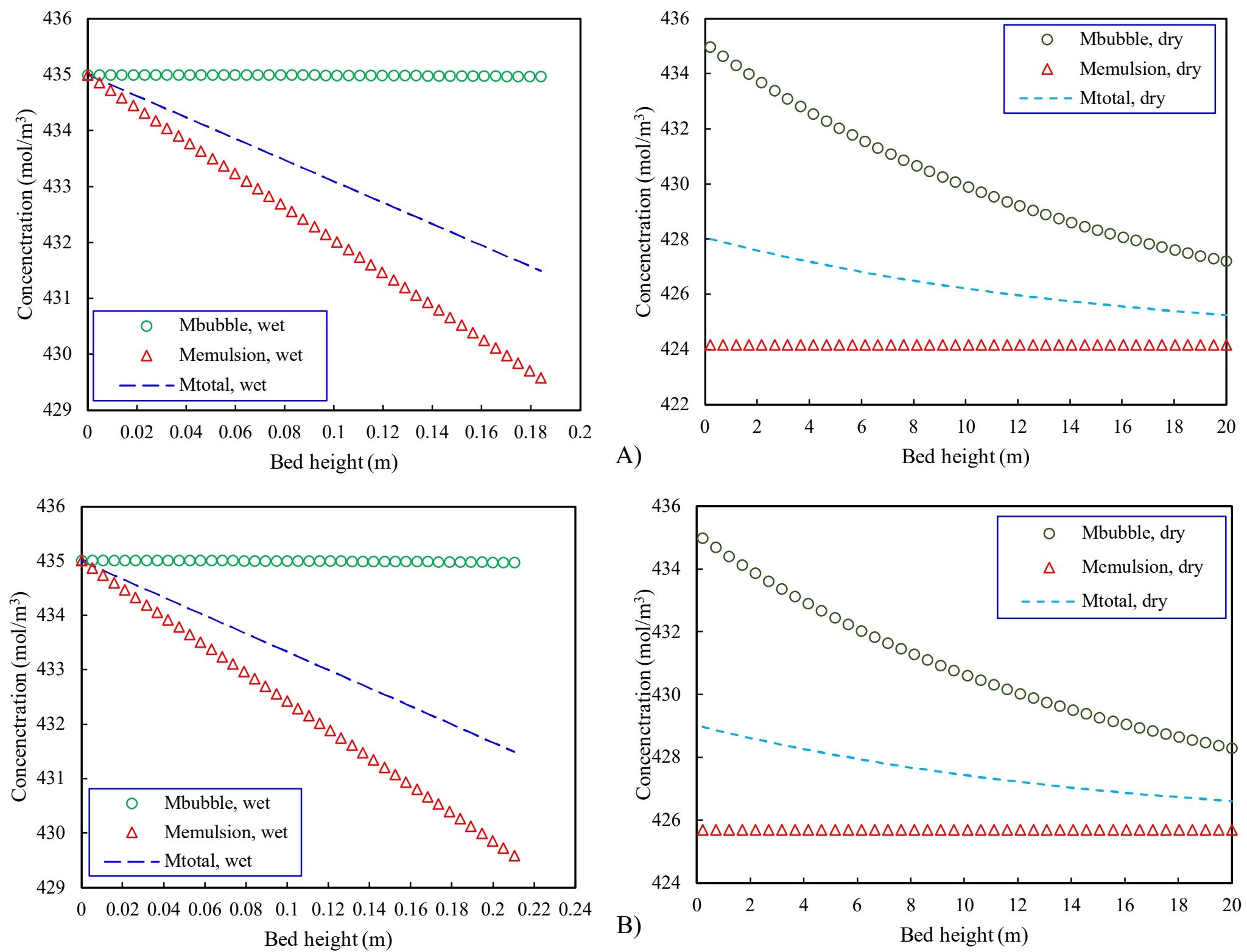

Figure S4: Effect of ICA flowrate on concentration profile along the bed in wet and dry zones,

a) $\left.\dot{\mathrm{m}}_{\mathrm{ICA}}=70 \mathrm{ton} / \mathrm{hr}, \mathrm{b}\right) \dot{\mathrm{m}}_{\mathrm{ICA}}=80 \mathrm{ton} / \mathrm{hr},\left(\mathrm{D}_{\mathrm{b}}=0.10 \mathrm{~m}, \mathrm{U}_{0}=0.65 \mathrm{~m} / \mathrm{s}, \mathrm{Q}_{\text {cat }}=0.31 \mathrm{gr} / \mathrm{s}\right)$ 

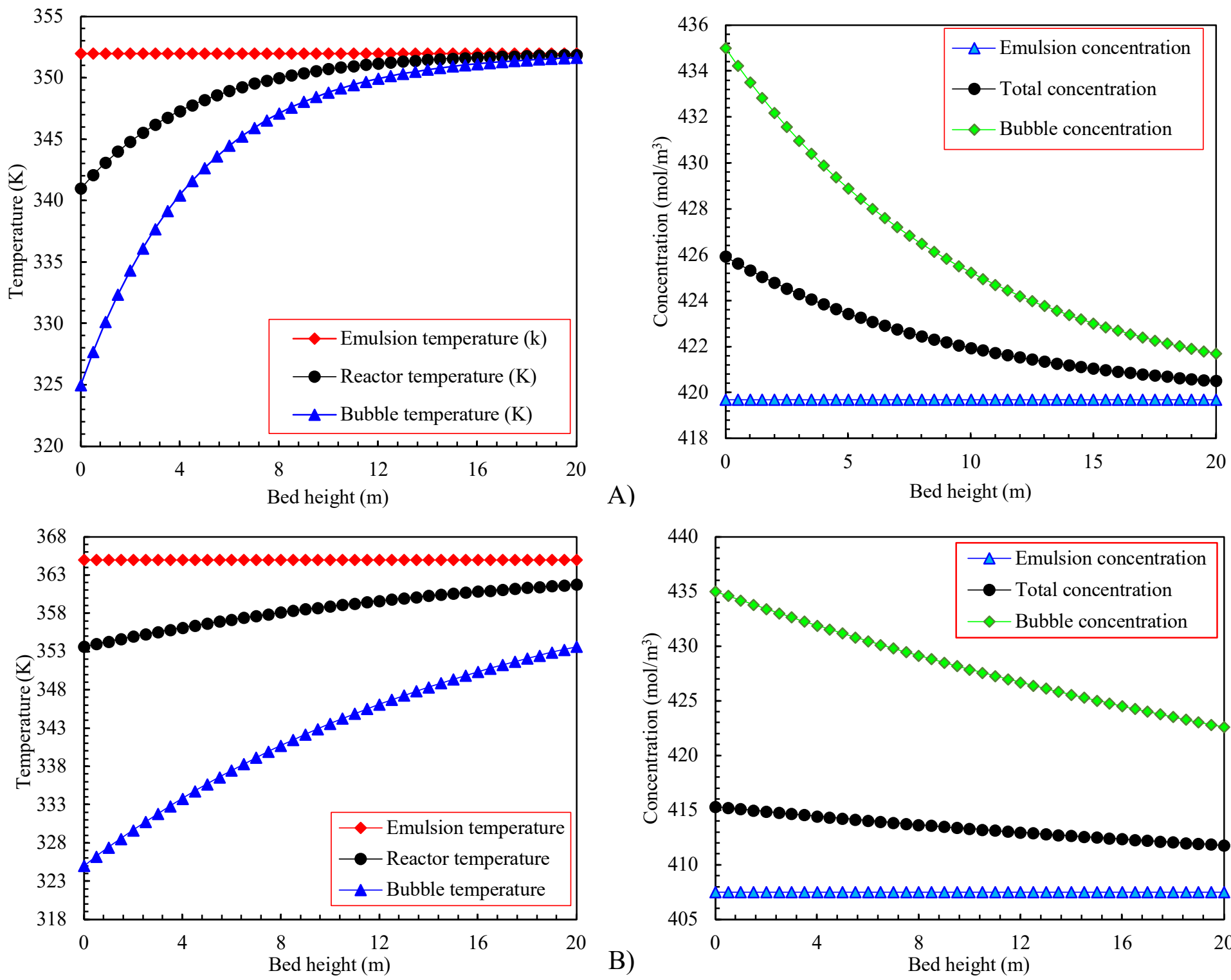

A)

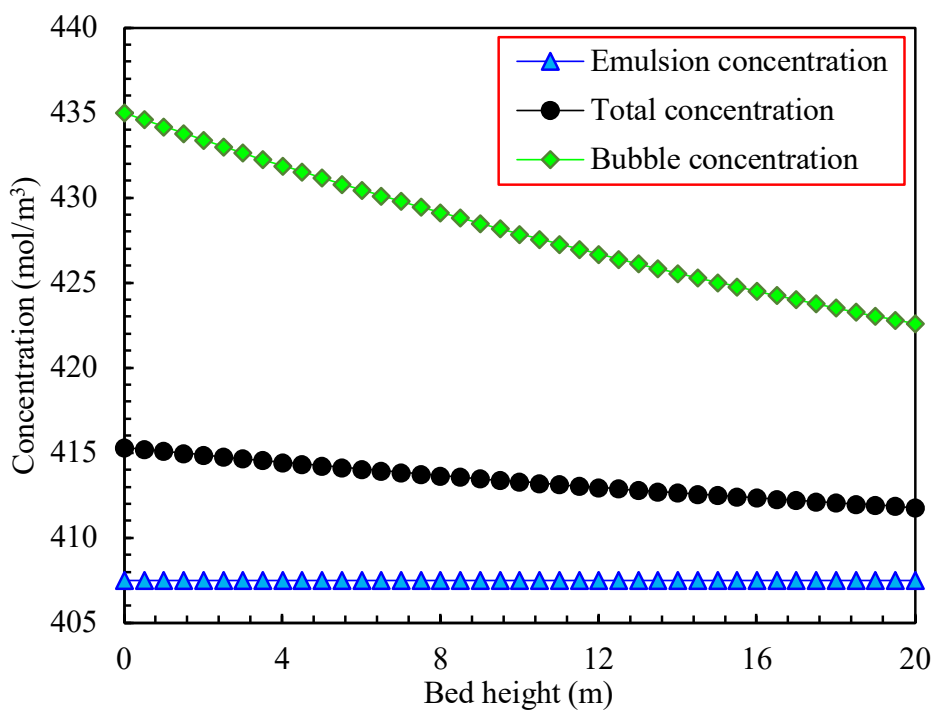

Figure S5: Effect of bubble size on temperature and concentration profiles along the bed,

a) $\mathrm{D}_{\mathrm{b}}=0.10 \mathrm{~m}: \Delta \mathrm{T}_{\text {approach }}=0.37 \mathrm{~K}, \Delta \mathrm{C}_{\text {approach }}=2.00 \mathrm{~mol} / \mathrm{m}^{3}$,

b) $\mathrm{D}_{\mathrm{b}}=0.20 \mathrm{~m}: \Delta \mathrm{T}_{\text {approach }}=11.37 \mathrm{~K}, \Delta \mathrm{C}_{\text {approach }}=15.07 \mathrm{~mol} / \mathrm{m}^{3}$

$\left(\mathrm{U}_{0}=0.65 \mathrm{~m} / \mathrm{s}, \dot{\mathrm{m}}_{\mathrm{ICA}}=65 \mathrm{ton} / \mathrm{hr}, \mathrm{Q}_{\mathrm{cat}}=4 \mathrm{~kg} / \mathrm{hr}\right)$ 

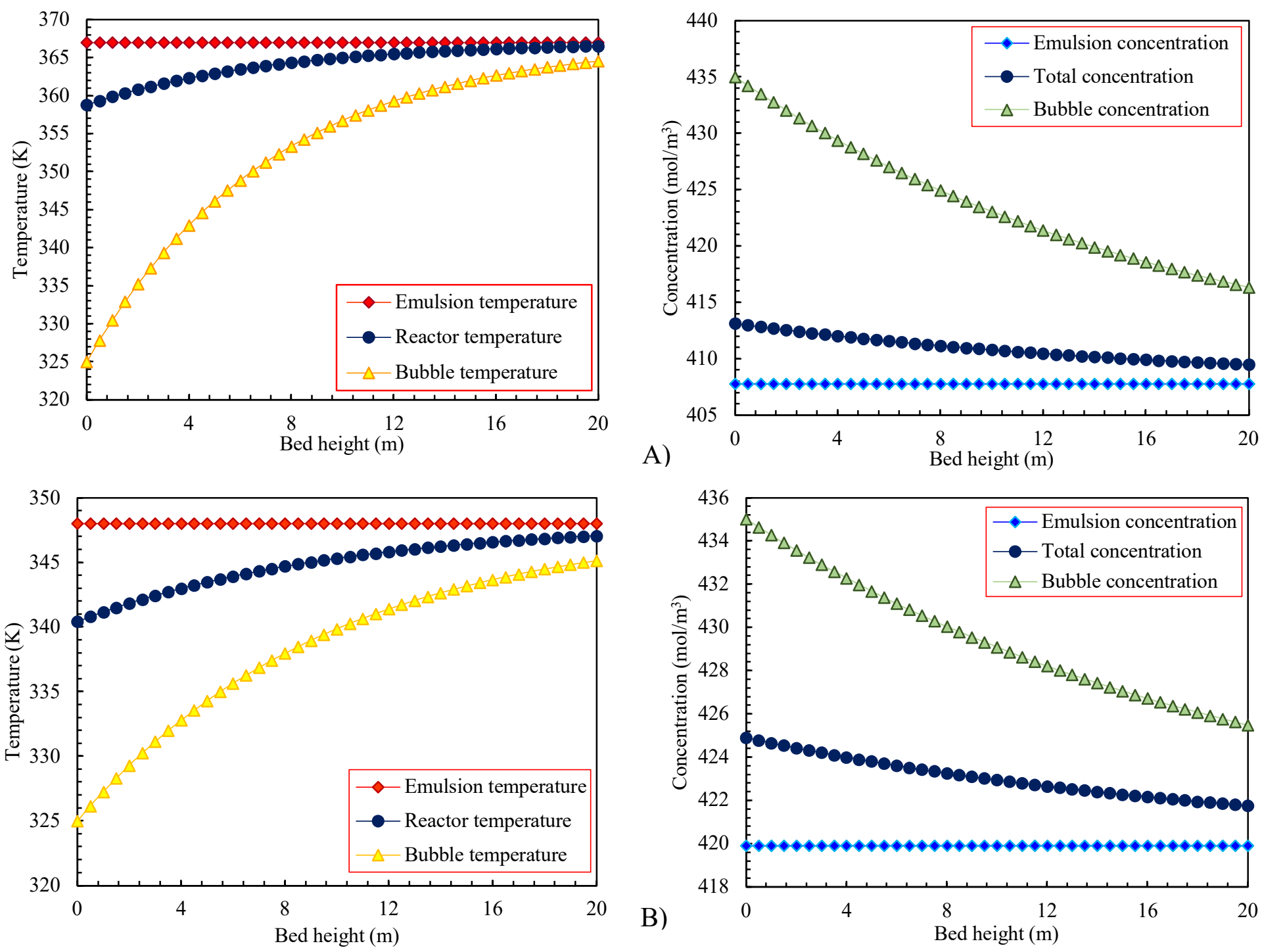

Figure S6: Effect of gas velocity on temperature and concentration profiles along the bed,

a) $\mathrm{U}_{0}=0.45 \mathrm{~m} / \mathrm{s}: \Delta \mathrm{T}_{\text {approach }}=2.44 \mathrm{~K}, \Delta \mathrm{C}_{\text {approach }}=8.55 \mathrm{~mol} / \mathrm{m}^{3}$,

b) $\mathrm{U}_{0}=0.65 \mathrm{~m} / \mathrm{s}: \Delta \mathrm{T}_{\text {approach }}=2.85 \mathrm{~K}, \Delta \mathrm{C}_{\text {approach }}=5.56 \mathrm{~mol} / \mathrm{m}^{3}$

$\left(\mathrm{D}_{\mathrm{b}}=0.15 \mathrm{~m}, \dot{\mathrm{m}}_{\mathrm{ICA}}=55 \mathrm{ton} / \mathrm{hr}, \mathrm{Q}_{\mathrm{cat}}=3 \mathrm{~kg} / \mathrm{hr}\right)$ 

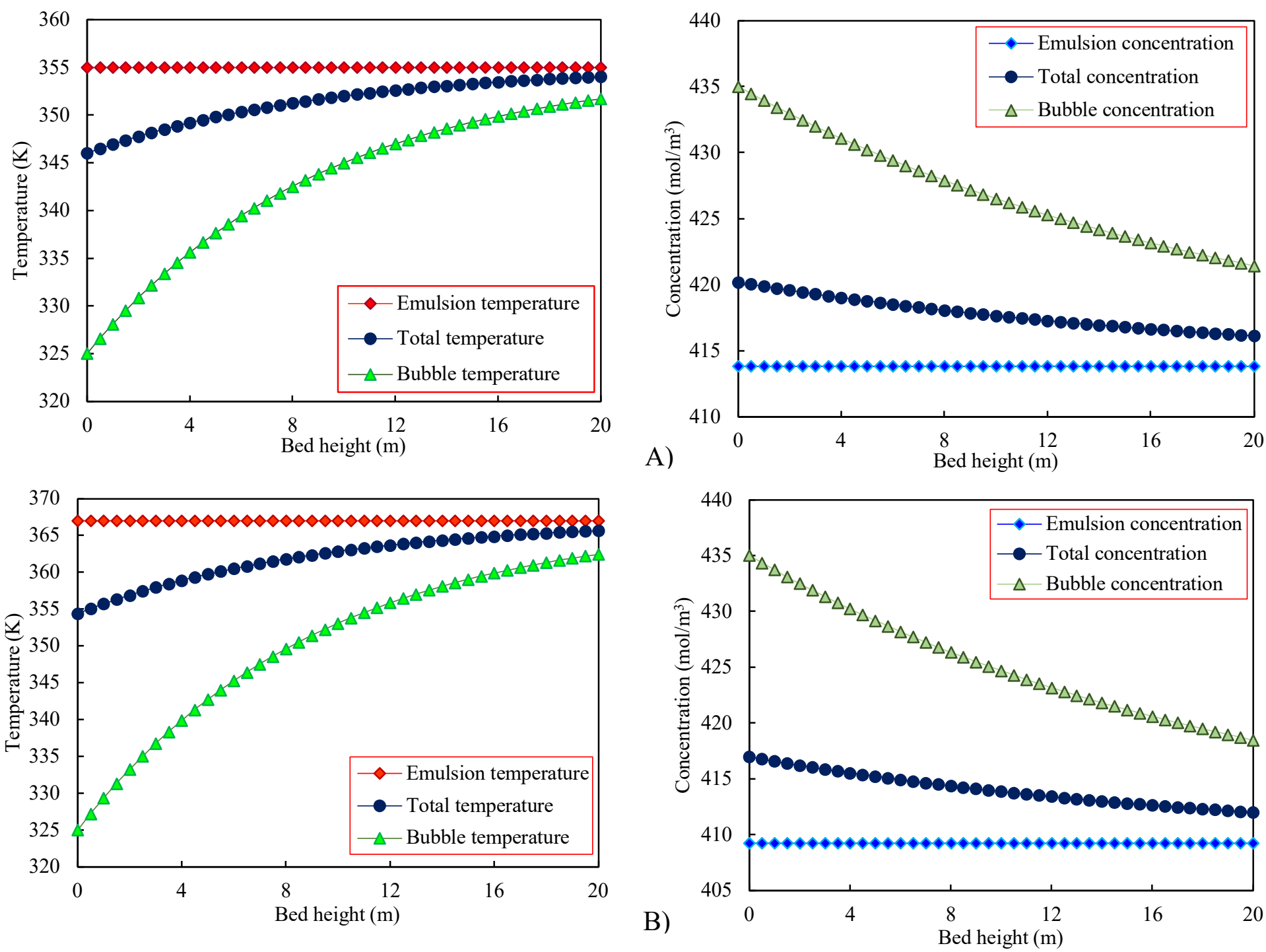

Figure S7: Result of Model I for the Effect of ICA flow rate on temperature and concentration profiles along the bed,

a) $\dot{\mathrm{m}}_{\mathrm{ICA}}=75 \mathrm{ton} / \mathrm{hr}: \Delta \mathrm{T}_{\text {approach }}=3.27 \mathrm{~K}, \Delta \mathrm{C}_{\text {approach }}=7.59 \mathrm{~mol} / \mathrm{m}^{3}$,

b) $\dot{\mathrm{m}}_{\mathrm{ICA}}=60$ ton $/ \mathrm{hr}: \Delta \mathrm{T}_{\text {approach }}=4.54 \mathrm{~K}, \Delta \mathrm{C}_{\text {approach }}=9.24 \mathrm{~mol} / \mathrm{m}^{3}$

$\left(\mathrm{D}_{\mathrm{b}}=0.15 \mathrm{~m}, \mathrm{U}_{0}=0.60 \mathrm{~m} / \mathrm{s}, \mathrm{Q}_{\mathrm{cat}}=4 \mathrm{~kg} / \mathrm{hr}\right)$ 


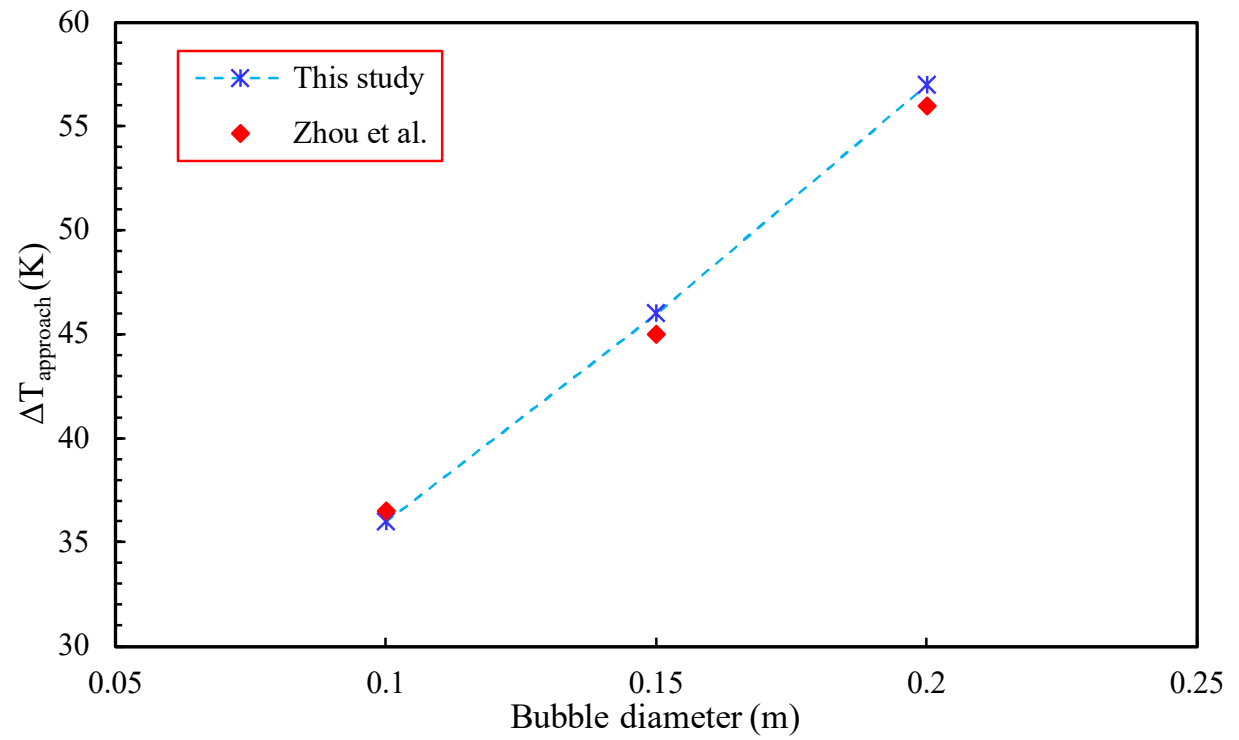

Figure S8: Comparison between results of Model II with that of Zhou et al. ${ }^{3}$ for $\Delta \mathrm{T}_{\text {approach }}$ in wet zone as a function of bubble diameter $\left(\mathrm{U}_{0}=0.65 \mathrm{~m} / \mathrm{s}\right)$ 

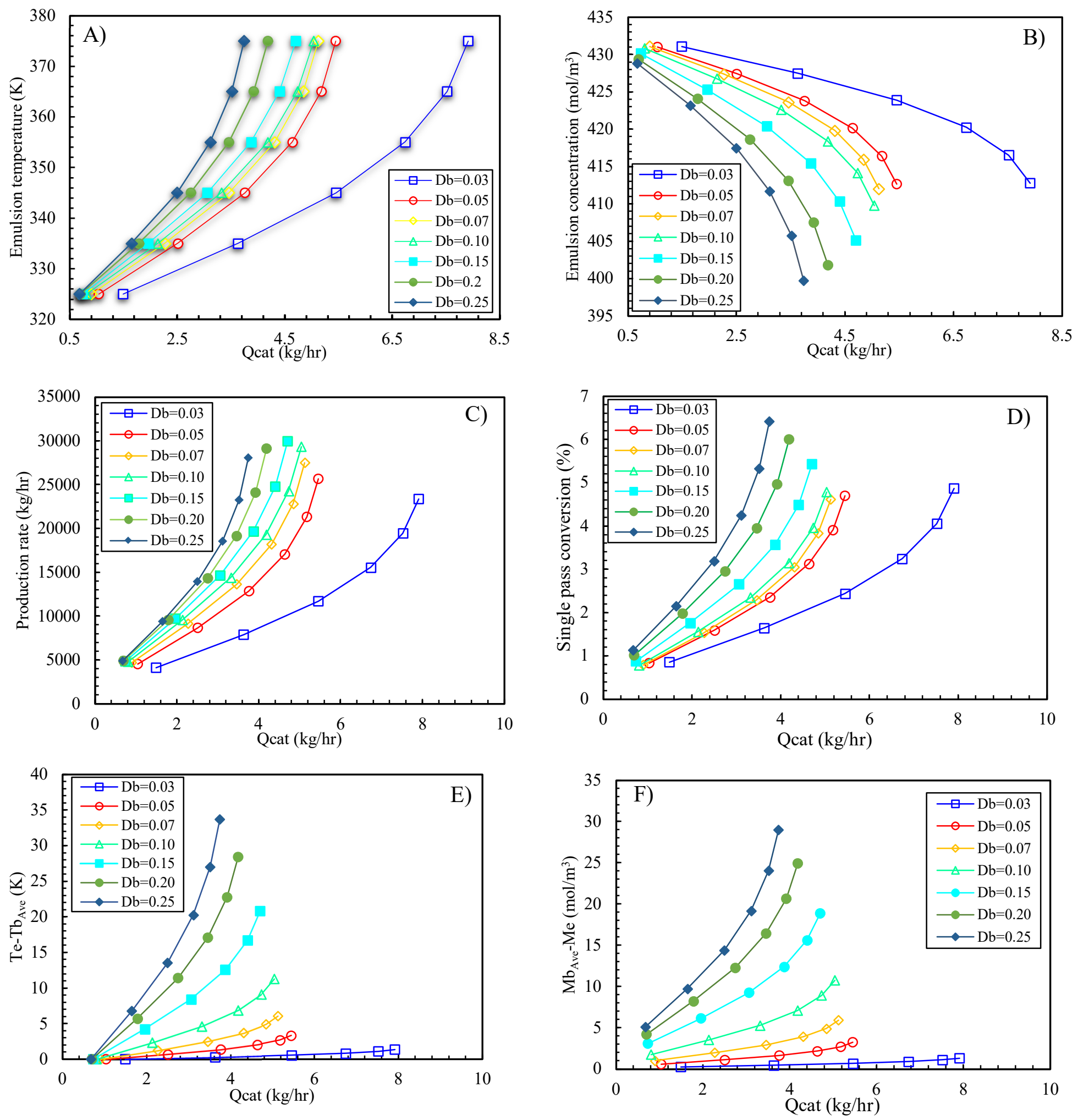

Figure S9: Effect of bubble diameter (m) and catalyst flowrate on: a) emulsion phase temperature, b) emulsion phase concentration, c) production rate, d) single-pass conversion, e) Temperature difference between emulsion and bubble phases, f) monomer concentration difference between emulsion and bubble phases, $\left(\mathrm{U}_{0}=0.65 \mathrm{~cm} / \mathrm{s}, \mathrm{M}_{0}=435 \mathrm{~mol} / \mathrm{m}^{3}, \mathrm{~T}_{0}=325 \mathrm{k}, \dot{\mathrm{m}}_{\text {ICA }}=60 \mathrm{ton} / \mathrm{hr}\right)$. 

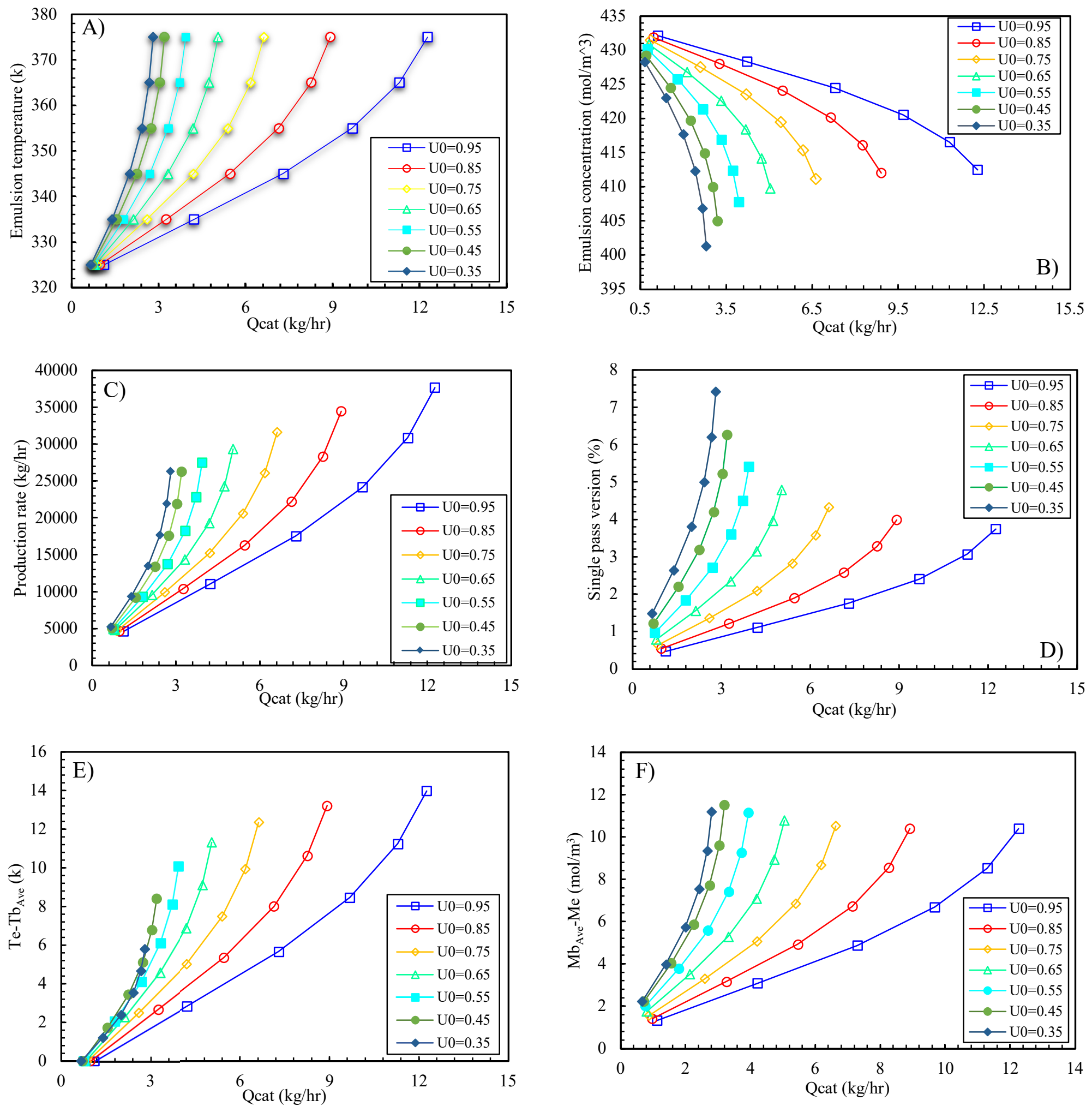

Figure S10: Effect of superficial gas velocity $(\mathrm{m} / \mathrm{s})$ and catalyst flowrate on a) emulsion phase temperature, $b$ ) emulsion phase concentration, c) production rate, d) single-pass conversion, e)

Temperature difference between emulsion and bubble phases, $\mathrm{f}$ ) monomer concentration difference between emulsion and bubble phases, $\left(\mathrm{d}_{\mathrm{b}}=0.10 \mathrm{~m}, \mathrm{M}_{0}=435 \mathrm{~mol} / \mathrm{m}^{3}, \mathrm{~T}_{0}=325 \mathrm{k}, \dot{\mathrm{m}}_{\mathrm{ICA}}=60 \mathrm{ton} / \mathrm{hr}\right)$. 
Table S1: Hydrodynamic correlations used for the two-phase models.

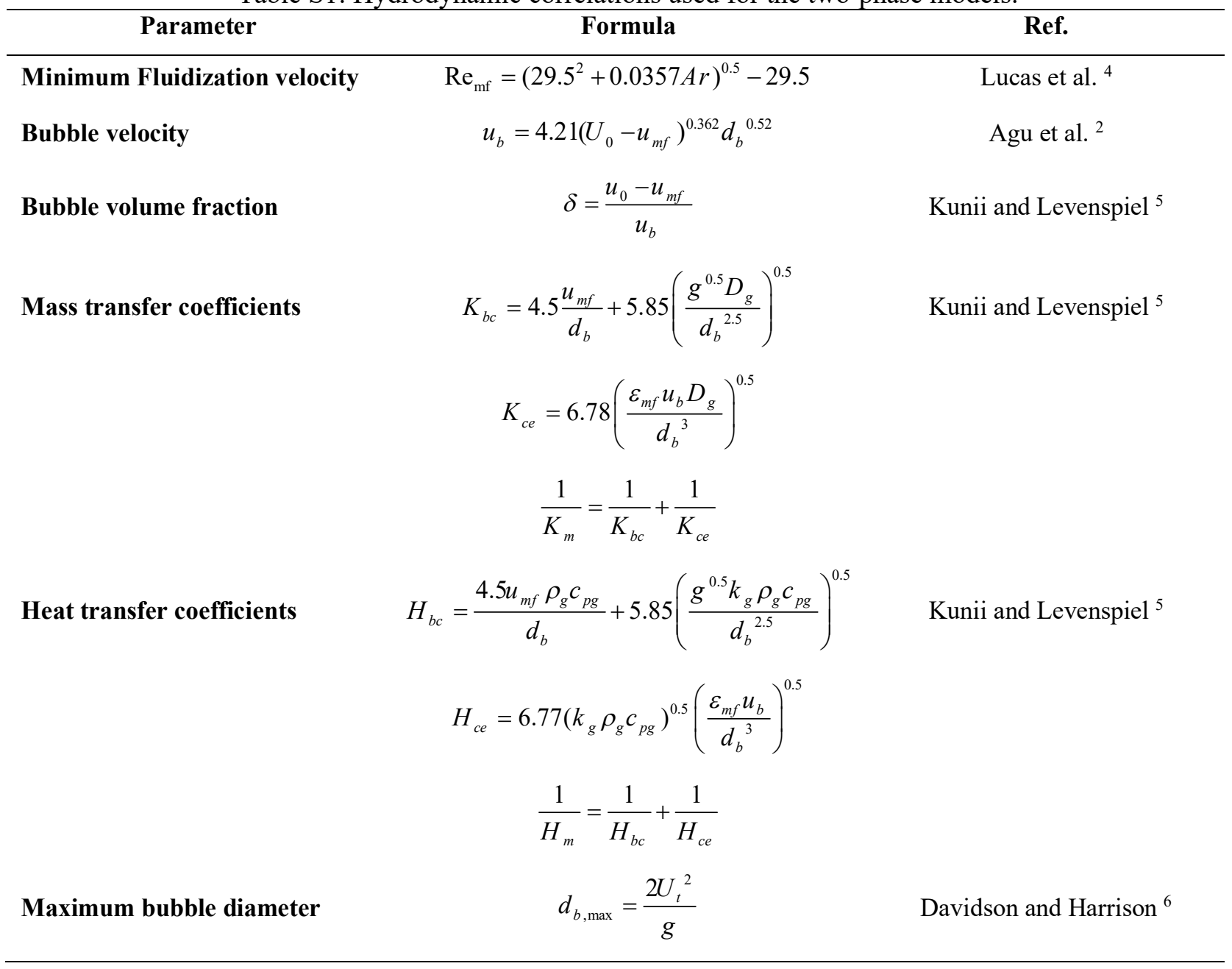


Table S2: Normal operating conditions of the industrial reactor and thermophysical parameters 3,7

\begin{tabular}{ll}
\hline Parameter & Value \\
\hline Gas viscosity, $\mu_{g}($ Pa.s $)$ & 0.000014 \\
Gas density, $\rho_{g}\left(\mathrm{~kg} / \mathrm{m}^{3}\right)$ & 26.70 \\
Gas thermal conductivity, $k_{g}(\mathrm{~W} / \mathrm{m} . \mathrm{k})$ & 0.0317 \\
Gas self-diffusion coefficient, $D_{g}\left(\mathrm{~m}^{2} / \mathrm{s}\right)$ & $4 \times 10^{-7}$ \\
ICA liquid density, $\rho_{l}\left(\mathrm{~kg} / \mathrm{m}^{3}\right)$ & 592 \\
Polyethylene density, $\rho_{p}\left(\mathrm{~g} / \mathrm{cm}^{3}\right)$ & 0.9190 \\
Polyethylene particle heat capacity, $C_{p p}(\mathrm{~J} / \mathrm{kg} / \mathrm{K})$ & 4004 \\
Pre-exponential factor of reaction rate, $k_{p 0}\left(\mathrm{~cm}^{3} / \mathrm{g}\right.$ cat $\left./ \mathrm{s}\right)$ & $4.16 \times 10^{6}$ \\
Activation energy for reaction rate, $\mathrm{E}_{\mathrm{a}}(\mathrm{J} / \mathrm{mol})$ & 37260 \\
Heat of polymerization, $\Delta H_{r}(\mathrm{~J} / \mathrm{g})$ & 3728 \\
Heat of vaporization, $\Delta H_{v}(\mathrm{~J} / \mathrm{g})$ & 367 \\
Average particle size,$d_{p}(\mu \mathrm{m})$ & 800 \\
Reactor height, $H(\mathrm{~m})$ & 20 \\
Reactor diameter, $D_{r}(\mathrm{~m})$ & 6 \\
Reactor pressure, $P(\mathrm{bar})$ & 22 \\
Superficial gas velocity, $U_{0}(\mathrm{~m} / \mathrm{s})$ & 0.65 \\
\hline
\end{tabular}

Table S3: Effect of hydrodynamic parameters on $\Delta \mathrm{T}_{\text {approach }}$ and $\Delta \mathrm{C}_{\text {approach }}$ of wet and dry zones.

\begin{tabular}{|c|c|c|c|c|c|}
\hline \multicolumn{2}{|c|}{ Hydrodynamic parameters } & \multicolumn{2}{|c|}{ Wet zone } & \multicolumn{2}{|c|}{ Dry zone } \\
\hline $\begin{array}{c}\text { Constant } \\
\text { parameters }\end{array}$ & $\begin{array}{c}\text { Changeable } \\
\text { parameter }\end{array}$ & $\Delta \mathrm{T}_{\text {approach }}(\mathrm{K})$ & $\Delta \mathrm{C}_{\text {approach }}\left(\mathrm{mol} / \mathrm{m}^{3}\right)$ & $\Delta \mathrm{T}_{\text {approach }}(\mathrm{K})$ & $\Delta \mathrm{C}_{\text {approach }}\left(\mathrm{mol} / \mathrm{m}^{3}\right)$ \\
\hline $\mathrm{U}_{0}=0.65 \mathrm{~m} / \mathrm{s}$ & $\mathrm{D}_{\mathrm{b}}=0.10 \mathrm{~m}$ & 35.91 & 5.36 & 0.57 & 1.28 \\
\hline$\dot{m}_{I C A}=70$ ton $/ \mathrm{hr}$ & $\mathrm{D}_{\mathrm{b}}=0.05 \mathrm{~m}$ & 16.91 & 4.95 & 0.00 & 0.00 \\
\hline $\mathrm{D}_{\mathrm{b}}=0.10 \mathrm{~m}$ & $\mathrm{U}_{0}=0.65 \mathrm{~m} / \mathrm{s}$ & 35.19 & 5.36 & 0.57 & 1.28 \\
\hline$\dot{m}_{I C A}=70 \mathrm{ton} / \mathrm{hr}$ & $\mathrm{U}_{0}=0.85 \mathrm{~m} / \mathrm{s}$ & 15.04 & 4.78 & 0.42 & 1.05 \\
\hline $\mathrm{D}_{\mathrm{b}}=0.13 \mathrm{~m}$ & $\dot{m}_{I C A}=70 \mathrm{ton} / \mathrm{hr}$ & 40.28 & 5.39 & 3.15 & 3.01 \\
\hline $\mathrm{U}_{0}=0.65 \mathrm{~m} / \mathrm{s}$ & $\dot{m}_{I C A}=80 \mathrm{ton} / \mathrm{hr}$ & 22.09 & 5.38 & 1.81 & 2.59 \\
\hline
\end{tabular}


Table S4: rate constants for Equation (42) in main manuscript $\left(\mathrm{T}_{\mathrm{ref}}=360 \mathrm{~K}\right){ }^{8,9}$

\begin{tabular}{lll}
\hline Kinetic constant & Unit & Value \\
\hline $\mathrm{k}_{\mathrm{p}}$ & $\mathrm{L} \mathrm{mol}^{-1} \mathrm{~s}^{-1}$ & 85 \\
$\mathrm{E}_{\mathrm{p}}$ & $\mathrm{cal} \mathrm{mol}^{-1}$ & 10000 \\
$\mathrm{k}_{\mathrm{tH}}$ & $\mathrm{L} \mathrm{mol}^{-1} \mathrm{~s}^{-1}$ & 0.024 \\
$\mathrm{E}_{\mathrm{tH}}$ & $\mathrm{cal} \mathrm{mol}^{-1}$ & 19821.21 \\
\hline
\end{tabular}

Table S5: Microstructure and mechanical properties of considered target resins

\begin{tabular}{ccccc}
\hline Target Resin No. & PSP2 & Pent $(\mathrm{hr})$ & SP-NCTL $(\mathrm{h})$ & NDR \\
\hline 1 & 12 & $5.7374 \mathrm{e}+03$ & $1.0284 \mathrm{e}+03$ & 497.8240 \\
2 & 14 & $8.1468 \mathrm{e}+04$ & $8.6521 \mathrm{e}+03$ & 405.9780 \\
3 & 16 & $1.1568 \mathrm{e}+06$ & $7.2792 \mathrm{e}+04$ & 314.1320 \\
4 & 18 & $1.6426 \mathrm{e}+07$ & $6.1241 \mathrm{e}+05$ & 222.2860 \\
5 & 20 & $2.3324 \mathrm{e}+08$ & $5.1523 \mathrm{e}+06$ & 130.4400 \\
\hline
\end{tabular}

Table S6: Obtained polymerization recipes along with other microstructure properties for resulted resins.

\begin{tabular}{cccccccc}
\hline $\begin{array}{c}\text { Target resin } \\
\text { No. }\end{array}$ & $\begin{array}{c}\mathrm{U}_{0} \\
(\mathrm{~m} / \mathrm{s})\end{array}$ & $\begin{array}{c}\dot{\mathrm{m}}_{\text {ICA }} \\
(\mathrm{ton} / \mathrm{hr})\end{array}$ & $\begin{array}{c}\mathrm{Q}_{\text {cat }} \\
(\mathrm{kg} / \mathrm{hr})\end{array}$ & $\begin{array}{c}\text { Obtained } \\
\mathrm{PSP} 2\end{array}$ & $\begin{array}{c}\text { Production } \\
\text { (ton/hr) }\end{array}$ & $\begin{array}{c}\text { Conversion } \\
(\%)\end{array}$ & $\begin{array}{c}\text { Emulsion phase } \\
\text { temperature }(\mathrm{K})\end{array}$ \\
\hline 1 & 0.55 & 120.00 & 5.19 & 11.39 & 37.1 & 3.7 & 371.25 \\
2 & 0.55 & 82.42 & 4.46 & 13.32 & 29.4 & 3.1 & 363.13 \\
3 & 0.69 & 115.26 & 5.27 & 15.51 & 30.01 & 2.1 & 359.51 \\
4 & 0.55 & 70.00 & 2.94 & 18.10 & 20.70 & 2.0 & 352.01 \\
5 & 0.75 & 70.00 & 3.18 & 20.06 & 18.33 & 1.2 & 346.93 \\
\hline
\end{tabular}




\section{S2. Imperialist competitive algorithm}

"Due to the same analogy between imperialist competitive algorithm (ICA) and the concept of imperialism, it will be beneficial to define imperialism and its parameters. In the following, we describe how ICA simulates this socio-political phenomenon in human life with the aim of a better understanding of the algorithm. From a historical point of view, the art of extending the power and rule of a country beyond its boundaries is called "Imperialism". This rule can be by direct domination or controlling, for example, trades and market of a colony. Whatever the reason is, strong competition between imperialist states takes place, which leads to the emersion of the powerful imperialists and the collapse of weaker ones ${ }^{10}$. As an example, in the $18^{\text {th }}$ century, Britain and France as two powerful imperialists have a strong competition to attract India as a part of their empire which the winner was Britain ${ }^{11}$. Following pacifying this country, not only telegraph lines, roads, railways, and English-speaking schools were developed by Britain in India, but also changes in social beliefs and customs of this colony were of achievements of Britain. Such attempts could not promote the control of imperialists over their colonies and history has shown that finally, colonies asked for their political autonomy. But the consequence for the colonies has been great social and political development ${ }^{11}$.

In the ICA approach, also imperialists are in a competing mode for taking possession of colonies of each other. It is interesting to note that assimilation policy is considered and modeled by approaching the colonies toward their corresponding imperialists. Figure S9 shows the flowchart of the ICA approach that is described in the following sections briefly ${ }^{12}$. 


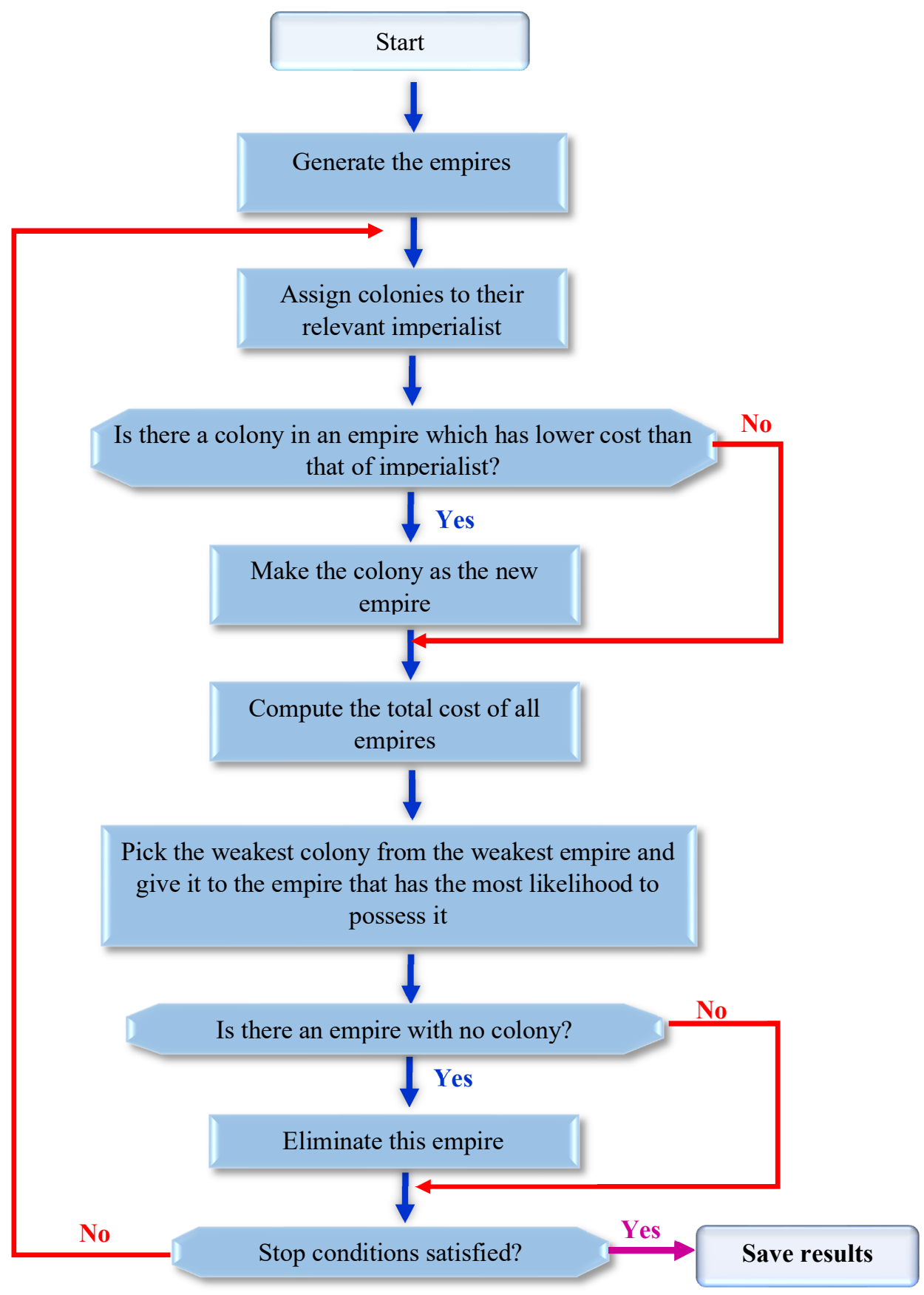

Figure S9: General flow chart of ICA. 


\section{S2.1. Generation of initial empires}

The algorithm starts with the generation of an initial population that comprises countries in the world. Some of the countries which much lower cost value, form imperialists and the rest are their colonies, which will be divided among the imperialists according to their power (Figure S10). In this regard, for a problem optimization consisted of $\mathrm{n}$ variables $\left(N_{\text {var }}\right)$ a country will be a $1 \times N_{\text {var }}$ array which is defined as below:

$$
\text { country }=\left[v_{1} \cdot v_{2} \cdot v_{3} \ldots . v_{N_{v a r}}\right]
$$

Then the cost of a country is calculated by evaluating the cost function for the country (i.e. at $\left.\left[v_{1} \cdot v_{2} \cdot v_{3} \ldots \cdot v_{N_{v a r}}\right]\right)$

$$
\text { cost }=f(\text { country })=f\left(v_{1} \cdot v_{2} \cdot v_{3} \ldots \cdot v_{N_{v a r}}\right)
$$

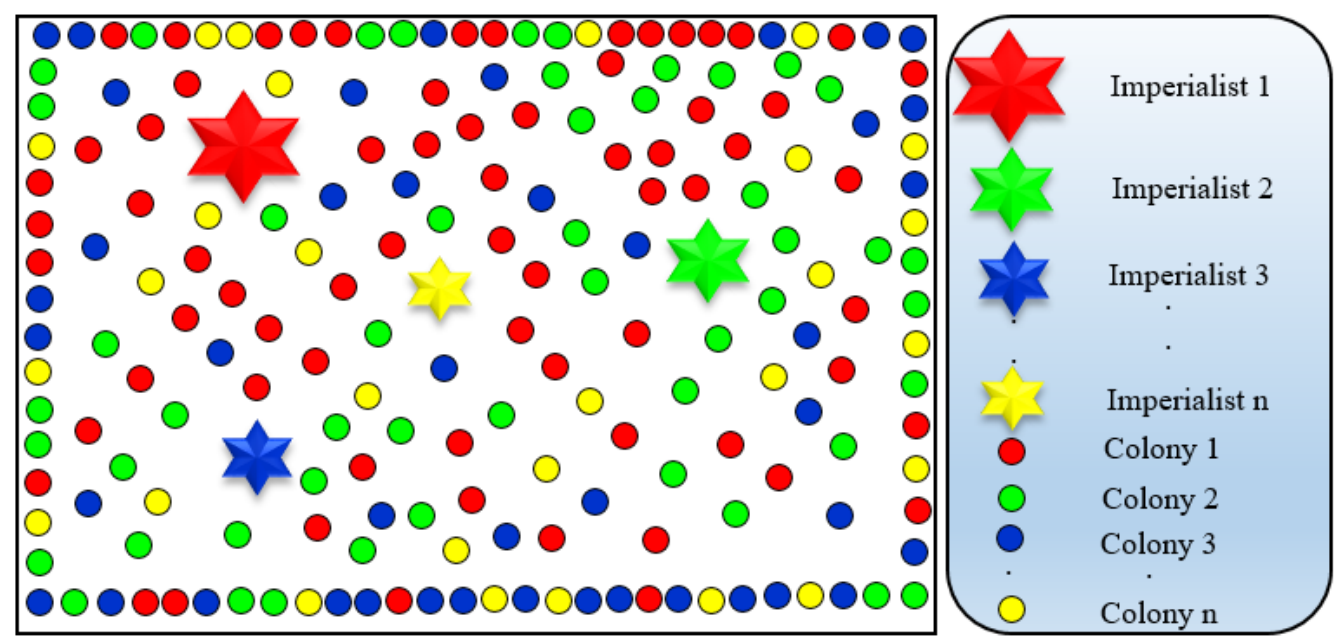

Figure S10: Schematic of generating initial empires. Imperialist with more colonies are bigger.

Then from the generated initial population of size $N_{\text {pop }}, N_{\text {imp }}$ which demonstrates the number of imperialists are selected from most powerful countries and the $N_{c o l}$ rest countries form the colonies that each of which belongs to an empire. The division of colonies between imperialists is based on their power calculated from the following relation: 


$$
p_{n}=\left|\frac{C_{n}}{\sum_{i=1}^{N_{i m p}} C_{i}}\right|
$$

where $C_{i}$ is the normalized cost of an imperialist defined by:

$$
C_{n}=c_{n}-\max \left\{c_{i}\right\}
$$

where $C_{n}$ is the normalized cost of the $\mathrm{n}^{\text {th }}$ imperialist and the cost of it is shown by $c_{n}$.

\section{S2.2. Assimilation}

After possesses of colonies to the imperialists, they start to move toward their relevant imperialist. Figure S11 shows the movement of a colony to imperialist where $x$ is a random variable that we have for it:

$$
x \sim U(0 . \beta \times d)
$$

where $d$ demonstrates the distance between imperialist and colony and $\beta$ is a number greater than 1 that $\beta>1$ results closer colonies to the imperialist location from both sides. However, with the aim of better searching around the imperialist, a parameter which is a measure of random deviation from the direction of movement ( Figure S11) has been considered in the ICA approach defined as below:

$$
\theta \sim U(-\gamma \cdot \gamma)
$$

where $\gamma$ is a parameter used to tune deviation from the original movement direction. 


\section{a)}

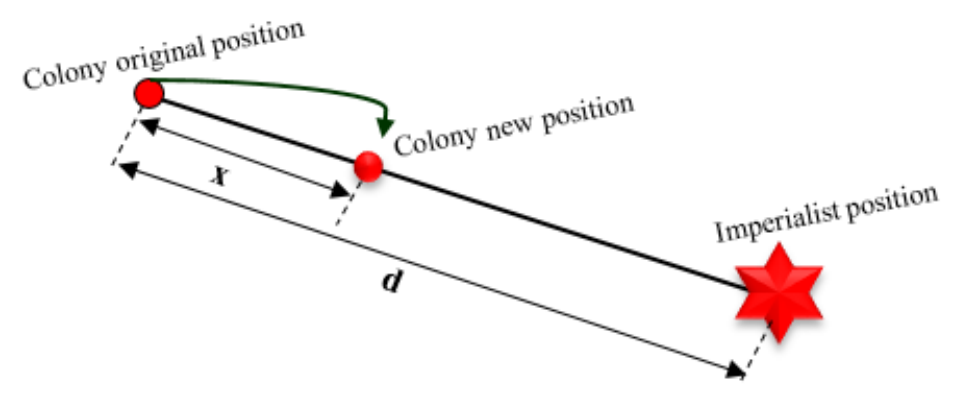

b)

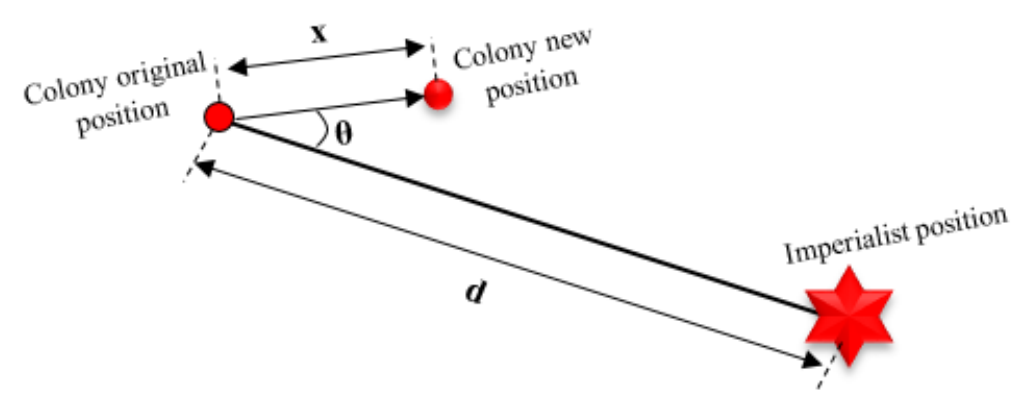

Figure S11: Moving type of colonies toward their imperialist position: a) direct movement, b) randomly deviated movement with a $\theta$ angle. Considering a random deviation in movement direction enables the model to search different points around the imperialist.

\section{S2.3. Revolution}

A fundamental and relatively sudden change in political power which occurs when the population revolt against the government due to perceived oppression likes economic and social is called the revolution. Inspired from political science, ICA has utilized such a feature to improve its performance for finding the global minimum of an objective function. Implementing revolution in the ICA approach, exploration behavior of the algorithm enhances, which in turn lead to the prevention of involving country with a local minimum in early convergence steps ${ }^{13}$. A random number between 0 and 1 is generated in each iteration. The generated random number is compared with the probability of revolution rate, which is a parameter of ICA. If the random number magnitude is lower than that of revolution rate probability, the revolution takes place. However, the new colony can be replaced with the previous one if its cost improved. Figure S12.A demonstrates a schematic of revolution procedure in the ICA approach. 

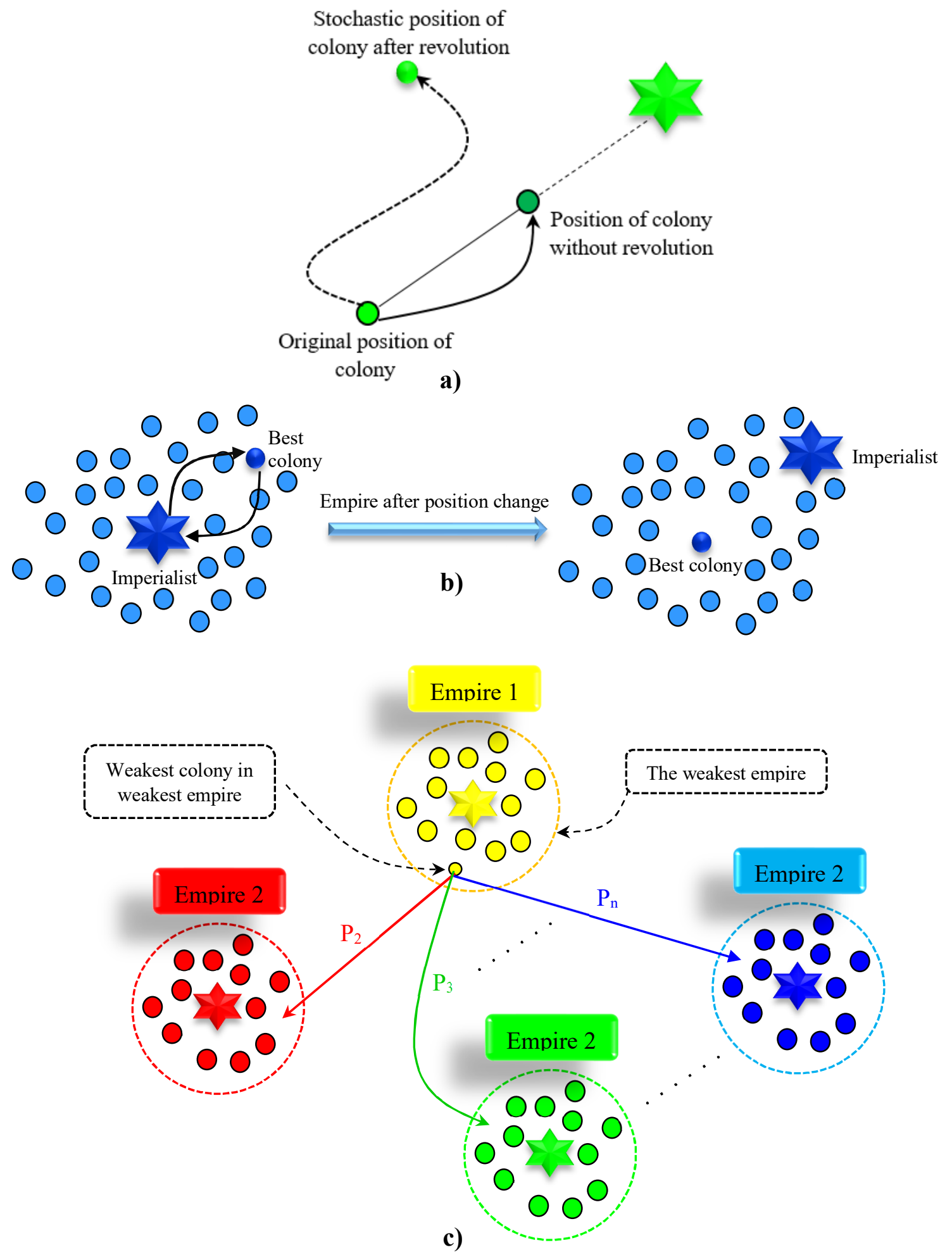

Figure S12: Different processes in ICA approach: a) Revolution, b) Position exchange of colony and its imperialist, c) Imperialist competition. 


\section{S2.4. Position exchange of a colony and its imperialist}

There is a possibility to exchange the position of a colony and its imperialist if the colony experience a position with a lower cost than that of the imperialist (Figure S12.B). After this exchange, the imperialist now starts to move toward the position of that colony. In such a case, the algorithm will continue by the new imperialist and other colonies of the empire start moving toward its position.

\section{S2.5. Imperialist competition}

To better understanding this step first we describe how the total power of an empire is calculated. The total power of an empire is mainly originated from the power of its imperialist. However, the power of the empire's colonies on the total power of the empire, whether negligible or egregious is considered in ICA and modeled as below:

$$
T C_{n}=\operatorname{Cost}(\text { imperialist })+\xi\left\{\text { mean }\left(\operatorname{cost}\left(\text { colonies of empire }{ }_{n}\right)\right\}\right.
$$

where $T C_{n}$ illustrates the total cost of the $\mathrm{n}^{\text {th }}$ empire and the $\xi$ is a positive number, which is generally less than 1 . Consequently, low values for $\xi$ lead to consideration of the total power of the empire to be just a function of an imperialist.

In this step, the competition of empires to take possession of colonies of other empires is started. This competition results in gradually decreasing of the power of weaker empires and thus an increase in the power of more powerful imperialists. This competition is modeled in ICA by picking one of the weakest colonies and creating competition between empires to possess it (Figure S10.c). It must be stressed that the colony will not necessarily be possessed by the most powerful imperialist. However, these empires have more chance to possess it. The possession probability of empire $\mathrm{n}\left(p_{p_{n}}\right)$ is obtained by:

$$
p_{p_{n}}=\left|\frac{N T C_{n}}{\sum_{i=1}^{N_{i m p}} N T C_{i}}\right|
$$


where $N T C_{n}$ is the normalized total cost of $\mathrm{n}^{\text {th }}$ empire given by:

$$
N T C_{n}=T C_{n}-\max \left\{T C_{i}\right\}
$$

\section{S2.6. Eliminating the powerless empires and convergence}

As the algorithm iterates the powerless empire collapse as a result of imperialistic competition. Thus, the colonies of collapsed imperialists are divided between other empires. In the ICA approach, when all the colonies of an empire loosed, the empire is removed from the algorithm search space. Continuing this way lead to collapsing all the empires except the most powerful one. In this regard, all the colonies of the algorithm are under the control of the most powerful imperialist. In this step, all colonies have the same position and the same cost compared to that of their imperialist and as a matter of fact, there is no difference between all colonies and imperialist. Such a condition is promising the end of the imperialistic competition and consequently, the end of the algorithm." 14 . 


\section{References}

(1) Davidson, J. F.; Harrison, D.; Jackson, R. Fluidized Particles: Cambridge University Press, 1963. 155 Pp. 35s. Elsevier 1964.

(2) Agu, C. E.; Tokheim, L. A.; Eikeland, M.; Moldestad, B. M. E. Improved Models for Predicting Bubble Velocity, Bubble Frequency and Bed Expansion in a Bubbling Fluidized Bed. Chem. Eng. Res. Des. 2019, 141, 361-371.

(3) Zhou, Y. F.; Wang, J. D.; Yang, Y. R.; Wu, W. Q. Modeling of the Temperature Profile in an Ethylene Polymerization Fluidized-Bed Reactor in Condensed-Mode Operation. Ind. Eng. Chem. Res. 2013, 52 (12), 4455-4464.

(4) Lucas, A.; Arnaldos, J.; Casal, J.; Puigjaner, L. Improved Equation for the Calculation of Minimum Fluidization Velocity. Ind. Eng. Chem. Process Des. Dev. 1986, 25 (2), 426429.

(5) Kunii, D.; Levenspiel, O. Fluidization Engineering; Elsevier, 2013.

(6) Davidson, J. F.; Harrison, D. Fluidized Particles, Cambridge University Press. Cambridge, New York 1963.

(7) McAuley, K. B.; Talbot, J. P.; Harris, T. J. A Comparison of Two-Phase and Well-Mixed Models for Fluidized-Bed Polyethylene Reactors. Chem. Eng. Sci. 1994, 49 (13), 20352045.

(8) McAuley, K. B.; MacGregor, J. F.; Hamielec, A. E. A Kinetic Model for Industrial Gasphase Ethylene Copolymerization. AIChE J. 1990, 36 (6), 837-850.

(9) Charoenpanich, T.; Anantawaraskul, S.; Soares, J. B. P. Estimation of Polymerization Conditions Needed to Make Ethylene/1-Olefin Copolymers with Specific Microstructures Using Artificial Neural Networks. Macromol. React. Eng. 2016, 10 (3), 215-232.

(10) Palmer, R. R.; Colton, J.; Kramer, L. S. A History of the Modern World; JSTOR, 1995; Vol. 2.

(11) Goff, R. D. The Twentieth Century: A Brief Global History; McGraw-Hill Companies, 1990.

(12) Atashpaz-Gargari, E.; Lucas, C. Imperialist Competitive Algorithm: An Algorithm for Optimization Inspired by Imperialistic Competition. 2007 IEEE Congr. Evol. Comput. CEC 2007 2007, 4661-4667.

(13) Mousavi Rad, S. J.; Akhlaghian Tab, F.; Mollazade, K. Application of Imperialist Competitive Algorithm for Feature Selection: A Case Study on Bulk Rice Classification. Int. J. Comput. Appl. 2012, 40 (16), 41-48.

(14) Atashrouz, S.; Rahmani, M.; Nasernejad, B.; Balzade, Z. Kinetic Prediction of Molecular Weight Distribution in Bimodal Polyethylene from Heterogeneous Post-Metallocene Catalysis. Mater. Chem. Phys. 2020, 255. 